\title{
FINANCIAL KNOWLEDGE FOR CORPORATE BOARDS: WHAT SHOULD BOARD MEMBERS KNOW?
}

\author{
José Miguel Pinto dos Santos \\ AESE Business School, Portugal \\ E-mail:jmps@aese.pt
}

Submission: 5/4/2020

Accept: 5/14/2020

\section{ABSTRACT}

Although there is a vast body of research on corporate governance and corporate boards, no one seems to have addressed yet the following question: What should corporate board members know of financial theory and practice to properly discharge their fiduciary responsibilities? The lack of reflection on this issue is somewhat surprising given the central role financial matters are supposed to play in board's discussions and decision making. The objective of this study is to offer a first reflection on this question. Different views of what a corporation is and who "owns" it, whether it is only shareholders or also a broader set of other stakeholders, result in different requirements concerning the financial knowledge board members should have. One such view is agency theory which considers that the main role of management is to create value for shareholders. From this perspective it will follow that board members should understand primarily the dynamics of value creation, with the concomitant focus on long-term strategy formulation. Another view is stakeholder theory which stresses the importance of the survival of the corporation. In this case the board should be conversant primarily with short term financial management, specially cash or liquidity management. The counterintuitive result is that when the board gives priority to the interests of shareholders, in opposition to the interests of other stakeholders beyond what law and good commercial and management practice recommends, it should focus primarily on long time value creation, while the more inclusive stakeholder view requires more attention on short-term cash management.

Keywords: financial knowledge; agency theory; stakeholder theory; Board of Directors; corporate governance 
ISSN: 2236-269X

DOI: 10.14807/ijmp.v12i1.1339

\section{INTRODUCTION}

One of the main responsibilities of corporate boards is to supervise the management of their business organization. An important element of this supervisory role is made through the analysis of budgets and financial reports. However, many board members are not financial specialists and not a few lack the most basic knowledge of accounting and corporate finance. The purpose of this article is to present the results of a reflection on what financial knowledge board members should possess to properly discharge the responsibilities they took on upon accepting a seat in a corporate board.

The nature of this question requires knowing to what entities or persons the corporate board members are ultimately responsible. To whom do board members owe their final allegiance has been a widely debated issue which, besides being relevant for the present quest on what financial knowledge board members should possess, has been important in the debates held in wider areas of research and practice such as corporate management and governance, corporate social responsibility and ethics, competition policy and regulation, to mention just a few areas.

Its importance is recurrently highlighted during financial and economic crises when public awareness to issues relating to corporate governance is heightened. Episodes of high profile corporate collapses, systemic failures, remuneration excesses, inadequate disclosure and accounting irregularities have significantly diminished public confidence in free markets and even in the free functioning of economic activity, have increased general distrust on corporate governance and public regulation, and have led to the proposal of different corporate governance models (Taylor, 2003).

The question of to whom corporate board members are ultimately accountable has received dissimilar answers from different corporate governance models. The view of whom the corporate board is responsible to depends fundamentally on one's views of what is a corporation. There are two main schools of thought concerning this question.

The first, and older view, is that a business corporation is an organization that belongs to its owners (in the sense they have a residual claim on its income and assets), the shareholders, whose purpose is to generate profits, or create value, and that should be managed in their best interests. In the well-known formulation of Milton Friedman the "responsibility [of corporate executives] is to conduct the business in accordance with [shareholders'] desires, which generally will be to make as much money as possible while conforming to the basic rules of 
DOI: 10.14807/ijmp.v12i1.1339

the society, both those embodied in law and those embodied in ethical custom.” (Friedman, 1970).

Accordingly, managers are agents of the shareholders, the "owners and employers" (Alchian \& Demsetz, 1972) or "risk bearers," (Easterbrook \& Fischel, 1989) owe them a fiduciary duty, and so are also the members of the board of directors, who, although through historical evolution manage directly no more, are entrusted with the duty of supervising closely the actions of the management team. This view has been represented in academic thought by the classical model of the firm, and more recently by agency theory (Jensen \& Meckling, 1976; Jensen, 2000).

The second view sees the corporation as something much more complex and richer than simply a business run on the behalf of its owners and having as its main purpose the attainment of a financial objective such as profit. It takes the shades of several competing but not wholly incompatible theories. The managerial theory of the firm (Baumol, 1959; Cyert \& March, 1963; Wikkiamson, 1964), the stakeholder theory (Freeman, 1984; Conger, Lawler \& Finegold, 2001), the stewardship theory (Donaldson And Davis, 1991), the resource-based view of the firm (Rumelt, 1984; Barney, 1991; Mcwilliams, Van Fleet \& Cory, 2002), and the institutional theory (Mcwilliams \& Siegel, 2001) are some of the theories that make the good performance of management, and explicitly or implicitly that of the board, dependent on its skill in balancing the interests of all groups having some relation with the corporation: managers themselves, shareholders, clients, workers, suppliers, government, future generations, etc. According to this view the composition of the board should ideally represent this variety of interests and one of its roles is to ensure that management appropriately balances them. One further responsibility of the board usually stressed by this view is that great care should be taken to ensure the continuity of the corporation (Palacios, 2003).

If the main duty of the board is to ensure that the corporation is managed on the best interests of shareholders and if these best interests are the maximization of the firm's value, it follows that members of the board should understand the dynamics of value creation. Value, and its relation to risk, expected returns, and expected cash flows is one basic topic of corporate finance that all undergraduate and graduate level courses and all major textbooks cover.

But if the main duty of the board to ensure the continuity of the corporation then arguably the board should pay special attention in avoiding what usually causes its dissolution: insolvency. This is a topic that is, at best, scantly dealt with by most finance textbooks. In what 
DOI: 10.14807/ijmp.v12i1.1339

follows we will briefly explore the implications that these two theories concerning the corporate model of organization have to a question seldom asked: what should board members know about financial theory and practice?

\section{SOME CHARACTERISTICS OF THE BUSINESS CORPORATION}

Though corporations have existed for a long time, the use of the corporate form by business enterprises is relatively new (Monks \& Minow, 2008). It started in the late sixteenth century but in restrictive conditions and with very limited numbers. Only a handful of cases existed before the second half of the nineteenth century, when incorporation conditions slowly became less stringent and the number of corporations started to rise (Laski, 1917; Cushing, 1915; Raymond, 1906).

Traditionally the usual form of business was the sole proprietorship, where there was no distinction between the merchant, or entrepreneur, and his business. This legal form was good enough for most cases during the first three thousand years of business history. With insight we now recognize that this form of business suffers from some limitations that place a too onerous burden on the business owner and consequently hamper innovation and economic development.

One is that the concern is too dependent on the person of its "owner." In many instances when the businessman dies so does the business. When this does not happen and his inheritors continue the enterprise, the personality of the business and the trust it inspires to its clients, suppliers and creditors can change so much as to become a business with a markedly different character, so dissimilar from the old as a son is different from his father or a wife from her husband.

The change of a CEO in a modern corporation can, without doubt, also change the personality of the company, but arguably the change is not as pronounced as in the case where a sole proprietorship changes hands: when a profligate son succeeded in the business of his prudent father, creditors immediately lined at his door. Another constraint is the amount of capital that a sole proprietorship can raise, which depends on the wealth of the businessman. In history we can find cases of merchants so rich, as Murayama Toan, that could easily finance new and fabulously expensive ventures with his accumulated wealth, as Toan's attempt to conquest Taiwan with his own private army in the late $16^{\text {th }}$ century, but these cases are exception (Kojima, 1989; Jansen, 1992). 
DOI: 10.14807/ijmp.v12i1.1339

More often than not, sole proprietorships face severe financial constraints on the expansion of their business operations. Still another limitation is the unlimited liability inherent to this business form: even though the merchant could allocate a part of his wealth to private use, for example to build a house to live in, this would not be free from claim in case his business became insolvent: all his possessions would answer for his debts irrespective of their origin and use. If his wealth was not enough to pay what he owed, he-and his family_could be put in prison or sold as slaves, his fate depending on the place and time he lived.

When the amount of capital needed for a business venture was larger than that one single merchant could muster, the traditionally established solution was the partnership. The partnership was formed by two or more merchants who would pool their resources, and its existence was limited up to the moment one of the partners left it. In a fashion similar to the sole proprietorship, all of the wealth of all partners answered for any debt incurred on the behalf of the partnership. Thus, trust amongst partners was crucial. The wealth of each and all partners would be a very relevant issue to take in consideration by the business counterparts of the partnership, as the ability to get paid would depend to a large extent on the aggregate wealth of all the partners.

Business corporations historically appeared when partnerships could not be used effectively to pool the necessary capital necessary to explore new business opportunities. This happened when, with the modern European overseas commercial expansion, the business enterprise required both an institutional stability and so large an amount of capital that no partnership could provide.

Large amounts of capital required many partners, but too many partners did not allow for the mutual trust necessary for partners to accept to incur in unlimited liability. The legal solution to this problem was the modern business corporation that has three main advantages over the previous two business forms. The first is legal personality independent of the individuals that originated it through the supply of capital. The second is limited liability of all capital suppliers.

The third is the free transferability of capital interests. The first characteristic permits the corporation to survive its founders and its business to avoid the disruption that the death of a sole proprietor or partner causes. The second allows the association of interests between complete strangers and between people of very different wealth. The third, made possible by 
DOI: 10.14807/ijmp.v12i1.1339

limited liability, allows the easy change of ownership to an extent impossible by sole proprietorships and partnerships.

The limitation of the liability that the providers of capital have in a corporation, by externalizing some of the costs of its activities to others, and reducing considerably their risk, had revolutionary consequences to the economic development of the world, but was resisted by some legal scholars and legislatures. Until the end of the nineteenth century a special act of the legislature was required, in most countries and in all states in the US, for each new business incorporation. Ambrose Bierce reflects this deep-rooted historical distrust of the business corporation in his The Devil's Dictionary by defining it as "an ingenious device for obtaining individual profit without individual responsibility.” (Bierce, 1958)

On the other hand, the great number of providers of capital together with the great changeability of their composition gave rise to a fourth characteristic of the business corporation: centralized management (Clarck, 1986). Though initially directors were chosen by shareholders from amongst their ranks, in the first half of the twentieth century it became common to choose professional managers with little or no holdings of the corporation's equity: this marked the beginning of the separation of ownership and control.

Despite being clear whom the board of directors represented during the first three and a half centuries of history of the business corporation, nowadays there is a great variety of opinion concerning what constituencies it should stand for, how it should do it, and how effective it is actually doing it.

Not affecting, nor being essential for the discussion that follows, and for the sake of simplicity, we will omit here the consideration of other business forms such as trusts, mutuals and cooperatives.

\section{THE ROLE OF THE CORPORATE BOARD}

According to the General Corporation Law of the State of Delaware, § 141 (a), the responsibility of management of a corporation lies with its board of directors: "the business and affairs of every corporation [...] shall be managed by or under the direction of the board of directors.” (Balotti \& Finkelstein, 2017) Therefore, according to this statute, and other similarly worded laws in other countries, the board can either manage the corporation directly or have it managed under its direction.

However, as Peter Drucker remarked over half a century ago "in reality the Board as conceived by the lawmaker is at best a tired fiction.” (Drucker, 1954) By the time Drucker 
INDEPENDENT JOURNAL OF MANAGEMENT \& PRODUCTION (IJM\&P)

http://www.ijmp.jor.br

v. 12, n. 1, January-February 2021

ISSN: 2236-269X

DOI: 10.14807/ijmp.v12i1.1339

made this observation, boards had already become a powerless notional point between shareholders and management, having lost any personal relationship with the former and being completely dominated (through nominations, rewards, and demotions) by the latter.

To this lack of correspondence between law and organizational practice, can be attributed the blame for many of the corporate scandals and failures observed during the past years. The recognition that the board is an essential fulcrum between shareholders and management, necessary to the good functioning of the corporation, has renewed interest in how to make it effective. To this end it is important to think on how the relationship of the board with shareholders on one side, and with management on the other, may be improved, and whether the initial legal intent should be restored or reformed (Montgomery \& Kaufman, 2003).

The choice of entrusting the board of directors with the responsibility of managing the corporation arouse from several practical reasons. One originated from the number of shareholders, which may be very large. When there a large number of shareholders they cannot be consulted by management every time a decision needs to be made. As corporations cannot be run in permanent consultation or through consecutive referendums, the delegation by shareholders to the directors of the power to decide in a wide range of issues, that range from everyday matters to strategic decisions, becomes an obvious solution to a practical problem.

Another reason arises from the fact that, as corporations are the result of the association of interests of many different investors - with different tolerance for risk —, it cannot be run by consensus. Therefore, there is usually a gradation on the type of decisions that can be taken by each governing body: from everyday matters that the CEO can take or oversee, to strategic decisions, voted by the board, to issues concerning governance architecture and other structural decisions, such as changes to the articles of incorporation, that are reserved to the shareholders' general meetings.

Finally, though shareholders may know their own interests better than anyone else, they may still become better off if they entrust the running of their enterprise to a group of professionals with specialized skills in running businesses (Fama \& Jensen, 1983).

One of the rights shareholders have is to elect the members of the board. Historically this power to elect sprang from the reasons mentioned above, including the impossibility of all shareholders being involved in the management of the corporation. However, this is not a sufficient reason for directors to represent only shareholders' interests. Their election can be 
DOI: 10.14807/ijmp.v12i1.1339

seen as no more than a screening process whereby shareholders have a veto power over nominations to the board without having any active role in the choice of directors. Even "in the team or nexus of contracts view of the firm, one cannot rule out the evolution of boards of directors that contain many different factors of production (or their hired representatives), whose common trait is that their marginal products are affected by those of the top decision makers” (Fama, 1980).

There are two main reasons why directors should represent the interests of shareholders. The first one is legal. In most jurisdictions the law requires, or at least assumes, that the corporation should be run according to the interests of shareholders, and clearly prescribes a fiduciary duty of directors to shareholders. Under statute or common law directors do not owe fiduciary duty to other groups, such as employees, customers, suppliers, or the society at large (Baxt, 2005; Ochiai, Kanda \& Kondo, 1990) — but societal attitudes have evolved, as shown by the recent "Statement on the Purpose of a Corporation" issued by the US based Business Roundtable (Business Roundtable, 2019) and may lead to legal changes in the near future (Bostock, 2000; Gelter \& Helleringer, 2015), especially if other institutions, like for example labour unions, continue to lose either their purpose or their effectiveness. The second is organizational. By design, the board is the only internal body that can be a check to management. A dysfunctional or de facto powerless board will not constitute a restraint to inappropriate managerial decisions.

Most jurisdictions impose two basic fiduciary duties on the members of the board. The first is the duty of loyalty, which requires that a director acts on the best interests of the shareholders, as is the case in the US, or of the corporation itself, as happens in the UK, Portugal (Wolters, 2006) and Japan (Japanese Government, 2020). The second is the duty of care, that requires directors to exercise due diligence when making decisions.

Whether the duty of loyalty has as its object shareholders or the corporation it has far reaching consequences that are beyond the scope of this study. It will suffice to note that the first view fits better with agency theory and the second adjusts better to stakeholder theory.

Though there are variants (Eisenhardt, 1989), the basic idea of agency theory is that in the business corporation there is a contract between a principal (the shareholders) and an agent (management) among whom may arise partial goal discrepancies whose alignment implies costs but is necessary to achieve efficiency of organization. Actually, the whole firm can be regarded as composed by a web of contracts between capital providers, labour providers, 
INDEPENDENT JOURNAL OF MANAGEMENT \& PRODUCTION (IJM\&P)

http://www.ijmp.jor.br

v. 12, n. 1, January-February 2021

ISSN: 2236-269X

DOI: 10.14807/ijmp.v12i1.1339

management specialists and others, so that it can be said that it is not owned by any of these groups in any meaningful way (Fama, 1980). Still management is under a contractual bond with capital providers to increase the value of their equity holdings-this being the only objective all shareholders would be able to agree among themselves, provided the Fisher separation theorem holds (Copeland \& Weston, 1988).

The stakeholder theory argues that a corporation is an organic composite of multiple and diverse interests that competes for survival with other organizations under the direction of managers. Therefore, management should tailor its policies to serve the purposes not just shareholders but also of all its constituencies such as customers, workers, suppliers, and the community where it operates. This view, though not having yet strong legal footing, is widely held not only by management academics but by a large fraction of managers and board members (Business Roundtable, 2019).

As most stakeholders derive their rewards from the corporation through long spans of time, their first interest lies in the continuity of the organization. In contrast to this, it may be pointed that there are instances when shareholders may have the opposite interest, that is when the value of their equity is maximized by management betting the survival of the firm through the taking of high risk, high expected return managerial decisions (Brealey \& Myers, 2006).

Moreover, even though shareholders, as residual claimants, also suffer the direct consequences of failure, they can shift among investments with relatively low transaction costs - at least lower than those faced by some of the other stakeholders such as workers and some suppliers - and hedge their risk on any given company through diversification. Besides the stakeholder theory other theories also argue that corporations should not be managed solely on the basis of shareholders' interests, that is, to maximize value. Given their similar position on this premise, and for the sake of simplicity, in what follows they will be grouped together, and collectively referred to, as 'stakeholder theories'.

\section{THE FINANCIAL KNOWLEDGE NECESSARY TO BOARD MEMBERS}

Whether managers and board members should focus on their fiduciary duty to shareholders, or transcend it in their decision making by taking into account all legitimate interests of other stakeholders, so arguably the knowledge concerning financial theory and practice they ought to possess in order to properly discharge their duty of care will be different.

Let us start with the view that managers should pursue value maximization and that it is the function of the board to monitor its achievement. Assume for a moment that the 
DOI: 10.14807/ijmp.v12i1.1339

appropriate value to maximize is enterprise value. Enterprise value (EV) is equal to the expected future free cash flows (FCF) discounted at an appropriate discount rate. In the usual case where the corporation raises capital through several sources, including both equity and debt, the appropriate discount rate is the weighted average cost of capital (WACC). This can be expressed in mathematical form as:

$E V_{0}=\sum_{t=1}^{\infty} \frac{F C F_{t}}{\left(1+W A C C_{t}\right)^{t}}$

From this equation it can inferred what managers and board members should know about finance. This can be done considering the two independent variables FCF and WACC.

The first is FCF: ceteris paribus, the higher the value of the expected FCF at a certain future moment the higher will be the enterprise value. Given market conditions, FCF at any moment in time depends on the production capacity of the firm, which in turns depends on the accumulated investment made up to that point. Therefore, first of all, board members should be able to evaluate investments.

To maximize value, management has to choose those investments that yield the highest expected present value of future FCFs. To do this, managers need to have a good grasp of the markets where the corporation can invest, their probable future evolution, and be able to select those that are more promising. Thus, they should be knowledgeable about corporate strategy and marketing. But to be able to make the best decisions they will have to be familiar with the techniques of capital budgeting, know how to evaluate projects with different life spans, be able to solve constrained capital budgeting problems, and understand capital budgeting procedures. Finally, familiarity with real options is becoming a must.

Once the investments are made, they need to be operated, what is to say, managed. It is from daily operation that assets actually generate cash flows. This has to do with purchases from suppliers, production schedules, inventories, sales, payments and collections related to the goods and services the corporation produces, that is, it has to do with working capital management. This management function is usually in the hands of middle level or functional managers, monitored by the top management.

They seldom reach the board as it is generally expected that the CEO assures their efficient management. The board must deal with working capital management questions mainly after mergers and acquisitions and major restructuring, or when there are doubts whether the firm is being properly managed. Thus, except for a few corporations where efficiency of working capital management is at the core of their business model, in most cases 
DOI: 10.14807/ijmp.v12i1.1339

there is no strict need for a member of the board and expertise in this area can be required only to middle and top level managers (as agents and principals respectively).

In Figure $1 \mathrm{a}$ simplified balance sheet is presented. Enterprise value can be thought of as being composed by the sum of the value of assets that are already in place plus the value of assets in which the corporation will invest. On one hand, assets in place are managed by middle level managers supervised by the top management (the CEO). They include not only capital goods but also the net working capital necessary to their operation.

This is called value management. On the other hand, acquisition of growth assets, as well as divestures of assets in place, are proposed by top management and ratified by the board of directors. To the choice of which assets the corporation should invest is called value creation. Though top management should be able to understand the financial implications of both working capital management and asset acquisition and divesture, members of the board usually need only to worry about value creation, and middle management only about value management. This is shown schematically by the two arrows drawn at the bottom of Figure 2 .

\begin{tabular}{|c|c|}
\hline Assets & Liabilities \\
\hline Assets in place & Debt \\
\hline Growth assets & Equity \\
\hline
\end{tabular}

Figure 1: A simplified balance sheet

The second variable of interest is the WACC. Given FCF, enterprise value is maximized through the minimization of the cost of capital. Hence board members should understand the implications that different capital structures have on the cost of capital. To this end they should be knowledgeable about theories concerning the optimal capital structure and models of cost of capital, as well as being educated concerning the theories of interest rate formation and the term structure of interest rates, and the relationship between the expected rate of return and risk and other factors as modelled by the CAPM or factor models. 
DOI: 10.14807/ijmp.v12i1.1339

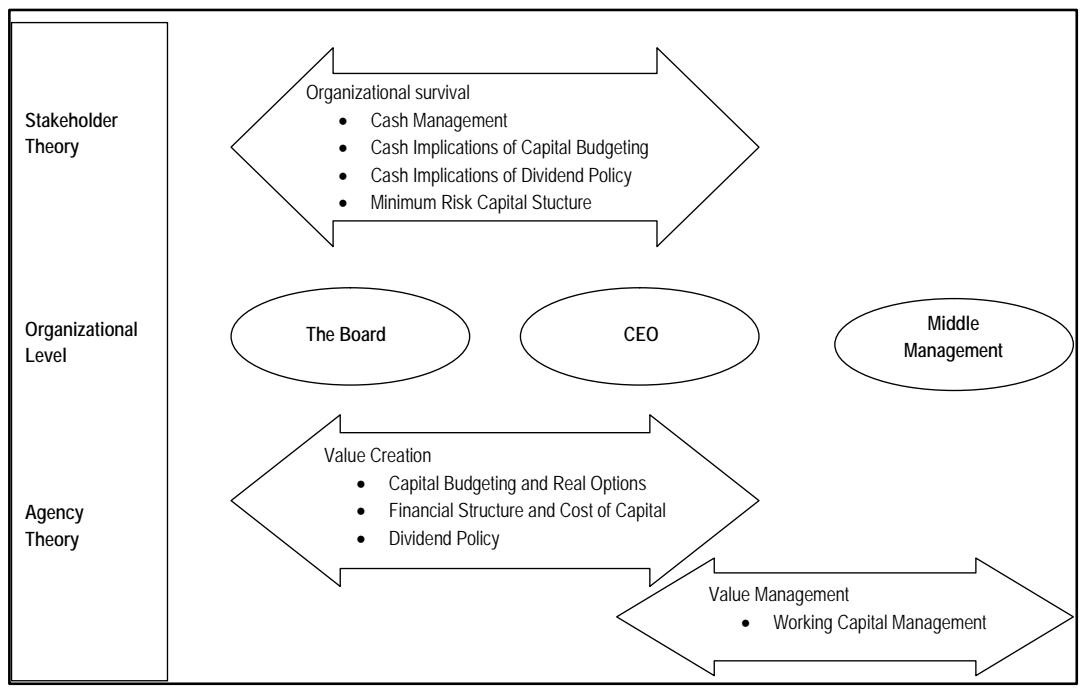

Figure 2: Areas of financial knowledge required of each organizational level as implied by the Agency and Stakeholder theories

Another variable affecting enterprise value may also be considered: time. In general, the longer the corporation is expected to generate positive FCF the higher will be its total value. Although in terms of strictly financial knowledge nothing from this variable can be required to the members of the board, it is still is crucial in drawing attention to the importance of longterm focus to enterprise value. Attention to long term will increase awareness of the importance that all stakeholders have to enterprise value because loyalty from employees, trusting relationships with suppliers and customers and support from communities and governments all have a positive impact on the growth and prosperity of the corporation.

If securities' markets are informationally efficient then there is equivalence between the value of a corporation's assets and the value of the claims against these assets (Modigliani \& Miller, 1958). Under these circumstances it is equivalent to maximize shareholder value or enterprise value. Shareholder value (P) is equal to the expected future dividend payments (Div) discounted at the rate of cost of equity $(k)$. In mathematical terms:

$P_{0}=\sum_{t=1}^{\infty} \frac{\operatorname{Div}_{t}}{\left(1+k_{t}\right)^{t}}$

Dividends are usually proposed by top management and ratified by the board. They affect the value of shares and sometimes are an important source of income to some groups of shareholders. Therefore board members should also be knowledgeable about dividend policy, being able to discern not only how important dividends are to their shareholders and what impact their changes will have on share prices, but also on the ability of the corporation to sell 
DOI: 10.14807/ijmp.v12i1.1339

new shares and the impact that their distribution will have in the financing needs of the corporation.

Let us now consider that the first objective of management should be the survival and continuity of the corporation. As Peter Drucker put it: "It is the first duty of a business to survive. The guiding principle, in other words, is not the maximization of profits; it is the avoidance of loss” (Drucker, 1954).

The precedence of survival as an objective over value creation or profitability is based on the rights some stakeholders have, namely workers, which can be assured only through the continued existence of the company. In contrast to profit maximization, survival seldom is considered as a financial objective. But even if continuity of the business organization is established as the first of its goals, board members will also need to know something about finance if they are to achieve this objective.

Needless to say, to avoid failure the board has to make decisions that also require knowledge in non-financial areas of management, mainly in the choice of markets where to operate. But in what concerns us here, what finance should board members know if they are to properly discharge their duty of care? Four main areas of expertise have already been proposed (Palacios, 2003).

As the most direct cause of failure is lack of cash board members should be able to detect early signs of possible liquidity problems. To avoid cash problems the first financial skill they need is to know how to use the cash budget. Cash budgets are the fundamental tools both to evaluate the consequences of alternative future courses of action, to guide management in the operation of the business, and to control its performance.

The second necessary area of knowledge is how to make investment analysis, not however with discounted cash flow techniques, but according to criteria that weed out projects that may cause cash shortages or losses in the short or medium-run with the accompanying dangers to the solvency of the corporation. The obvious reason is that investments are expenditures that usually are large and will cause either cash outlays or increases in debt. As any of these increases the danger of insolvency, every care should be exercised with capital expenditures.

Though practitioners use several rules of thumb to judge the impact an investment may cause on the cash position of the firm, including the payback period, these methods are largely ignored in most corporate finance manuals. This is because the value creation orientation that 
INDEPENDENT JOURNAL OF MANAGEMENT \& PRODUCTION (IJM\&P)

http://www.ijmp.jor.br

v. 12, n. 1, January-February 2021

ISSN: 2236-269X

DOI: 10.14807/ijmp.v12i1.1339

most textbooks follow puts strong emphasis on discounted cash flows, a methodology where these rules of thumb have no place. After making sure the investment does not endanger the cash position of the corporation, projects may be evaluated according to different criteria, including value creation, strategic positioning, specific stakeholder interest on the project, or politically enhancing reasons.

The third necessary area of expertise is in the management of debt-capital ratio. But again, not to minimize the WACC as when the objective is value maximization, but to choose among the possible capital structures which minimizes the risk of failure. One role of the board should then be to limit possible management over-eagerness for more debt to finance an everincreasing size of the corporation. Another role is to plan and manage necessary future changes in shareholder composition to align shareholders' clientele and their objectives with the needs of the corporation.

The fourth area that boards should master is dividend policy. Once again, the focus will be different from that of a value maximizing board as the decision on dividend payments will be constrained, first of all, by their impact on the cash needed in the near future. In general dividends are seen by those who consider survival of the organization as its principal mission as a necessary evil that should be minimized, constrained to the need the corporation will have to issue new equity in the future.

These four areas of financial knowledge are necessary to both members of the board and top management as is schematically shown in the arrow drawn at the top in Figure 2.

Investment analysis, capital structure and dividend policy are concerns common to both the value creation and the survival perspectives of corporations. The difference lies in the focus with which they approach these matters, and in the financial skills they demand of managers.

The underlying assumption of the theories that put survival of the corporation ahead of value creation is that capital and financial markets are neither efficient nor reliable sources of funds. One of their consequences is to put cash at premium, require caution on planned outlays and encourage management to hoard cash for precautionary motives. In contrast, theories that give precedence to value creation are more trustful of capital and financial markets; not being worried about cash shortages in the short or medium term, because the corporation will be able to procure the necessary funds at an appropriate rate, they allow management to give more attention to the future development of the business. 
DOI: 10.14807/ijmp.v12i1.1339

Pure types of management practice, either value maximizing or survival at all costs, are rarely found, most corporations' management falling somewhere in between these two extremes. Thus, usually most boards will have to analyse the financial implications of proposed policies using both sets of skills described above.

However, most financial education programs and literature assume value seeking behaviour. It is difficult, in fact, to find academic literature and adequate financial training geared towards corporate continuity or organizational survival.

\section{CONCLUSIONS}

Theories of the corporation can be roughly divided into two categories based on towards whom the responsibility of management is defined: shareholders or a broader set of stakeholders. The first set of theories hold that the first responsibility of management is to create value, the second one that it should seek to preserve the corporation as a viable entity. Depending on the primary objective of management, the financial skills that managers, and that of those that oversee them on the board of directors, will have to be different.

Though in both cases board members will have to decide matters on investments, capital structure and dividend policy, the financial skills required will be different. One will require focus on future free cash flows, how to obtain capital at low cost, and on the long run developments that might affect the corporation. The other will demand attention on cash generation and preservation and will, out of necessity, pay more attention to short run events.

\section{REFERENCES}

Alchian, A. A., \& Demsetz, H. (1972). Production, Information Costs, and Economic Organization. American Economic Review, 62(5), 777-795.

Balotti, R. F., \& Finkelstein (2017). Delaware Law of Corporations and Business Organizations Statutory Deskbook, 2017 ed. New York: Wolters Klugen Law \& Business.

Barney, J. (1991). Firm Resources and Sustained Competitive Advantage. Journal of Management, 17(1), 99-120.

Baumol, W. J. (1959). Business Behavior, Value and Growth, New York: Macmillan. Baxt, B. (2016). Duties and Responsabilities of Directors and Officers, 18th ed., Sydney NSW: Australian Institute of Company Directors.

Bierce, A. (1911). The Devil's Dictionary, Cleveland: The World Publishing Company. Bostock, T. (2000). To Whom Are Duties of a Company Director Owed? Unpublished Manuscript, Australian Institute of Company Directors and Centre for Corporate Law and Securities Regulation, The University of Melbourne: 1-20, Available: https://law.unimelb.edu.au/_data/assets/pdf_file/0019/1710172/138-bostock1.pdf. Access: 20/03/2020. 
Brealey, R. A., Myers, S. C., \& Allen, F. (2016). Principles of Corporate Finance, 12th ed. New York: McGraw-Hill Irwin.

Business Roundtable (2019). Statement on the Purpose of a Corporation. Available: https://opportunity.businessroundtable.org/wp-content/uploads/2020/04/BRT-Statement-onthe-Purpose-of-a-Corporation-with-Signatures-Updated-April-2020.pdf. Access: 24/04/2020.

Clark, R. C. (1986). Corporate Law, Boston: Little, Brown \& Co.

Conger, J. A., Lawler III, E. E., \& Finegold, D. L. (2001). Corporate Boards: Strategies for Adding value at the Top, San Francisco, CA: Jossey-Bass.

Copeland, T. E., \& Weston, J. F. (1988). Financial Theory and Corporate Policy, 3rd ed., Reading, Massachusetts: Addison-Wesley Publishing Company.

Cushing, H. A. (1915). Voting Trusts: A Chapter in Recent Corporation History. New York, McMillan Company.

Cyert, R. M., \& March, J. G. (1963). A Behavioral Theory of the Firm, Englewood Cliffs: Prentice-Hall.

Donaldson, L., \& Davis, J. H. (1991). Stewardship theory or agency theory: CEO governance and Shareholder Returns, Australian Journal of Management, 16(1), 49-64.

Drucker, P. F. (1954). The Practice of Management, New Cork: Harper \& Row.

Easterbrook, F. H., \& Fischel, D. R. (1989). The Corporate Contract. Columbia Law Review, 89(7), 1416-1448.

Eisenhardt, K. M. (1989). Agency Theory: An Assessment and Review. Academy of Management Review, 14(1), 57-74.

Fama, E. (1980). Agency Problems and the Theory of the Firm. Journal of Political Economy, 88(2), 288-307.

Fama, E., \& Jensen, M. (1983). Separation of Ownership and Control. Journal of Law and Economics, 26(2), 301-325.

Freeman, R. (1984). Strategic Management: A Stakeholder Approach, Boston: Pitman.

Friedman, M. (1970). The Social Responsibility of Business is to Increase Its Profits, New York Times Magazine, September 13, 1984, available:

http://umich.edu/ thecore/doc/Friedman.pdf. Access: 27/4/2020.

Japanese Government, Sh̄̄hō (Code of Commercial Law), §254, available: https://elaws.egov.go.jp/search/elawsSearch/elaws_search/lsg0500/detail?lawId=132AC0000000048. Access: 27/04/2020.

Gelter, M., \& Helleringer, G. (2015). Lift Not the Painted Veil! To Whom Are Directors' Duties Really Owed?, University of Illinois Law Review, 2015(3), 1069 -1118, available: https://ir.lawnet.fordham.edu/faculty_scholarship/963. Access 4/04/2020.

Jansen, M. B. (1992). China in the Tokugawa World, Cambridge, Harvard University Press.

Jensen, M.; Meckling, W. (1976). Theory of the Firm: Managerial Behavior, Agency Costs, and Ownership Structure, Journal of Financial Economics, 3(4), 305-360.

Jensen, M. C. (2000). A Theory of the Firm: Governance, Residual Claims, and Organizational Forms. Cambridge, Mass.: Harvard University Press. 
DOI: 10.14807/ijmp.v12i1.1339

Kojima Y. (1989). Murayama Toan: Sono Ai to Junan. Nagasaki: Seibo no Kishi-sha. Laski, H. J. (1917). The Early History of the Corporation in England, Harvard Law Review, 30(6), 561-588.

Mcwilliams A., Van Fleet, D. D., \& Cory, K. D. (2002). Raising Rivals’ costs through political strategy: An Extension of the Resource-Based Theory, Journal of Management Studies, 39(5), 707-723.

Mcwilliams A., \& Siegel, D. (2001). Corporate Social Responsibility: A Theory of the Firm Perspective, Academy of Management Review, 26(1), 117-127.

Modigliani, F., \& Miller, M. H. (1958). The Cost of Capital, Corporate Finance, and the Theory of Investments, American Economic Review, 48(3), 261-297.

Monks, R. A. G., \& Minow, N. (2008). Corporate Governance, 4th edition. West Sussex: John Wiley \& Sons.

Montgomery, C. A., \& Kaufman, R. (2003). The Board's Missing Link, Harvard Business Review, 81(3), 86-93.

Ochiai S., Kanda Y., \& Kondo K. (1999). Shōhō II Kaisha, 3rd revised Edition. Tokyo: Yuhikaku.

Palacios, J. (2003). Finanzas Para Consejos de Administración. Unpublished manuscript, V Encuentro Internacional de Professores de Política de Empresa, Instituto Internacional San Telmo, Sevilla, p. 1-25.

Raymond, R. L. (1906) The Genesis of the Corporation, Harvard Law Review, 19(5), 350365.

Rumelt, R. (1984). Towards a Strategic Theory of the Firm, in: Lamb R. (ed.), Competitive Strategic Management. Englewood Cliffs: Prentice-Hall.

Taylor, B. (2003). Corporate Governance: The Crisis, Investors’ Losses and the Decline in Public Trust, Corporate Governance: An International Review, 11(3), 155-163.

Williamson, O. E. (1964). The Economics of Discretionary Behavior: Managerial Objectives in a Theory of the Firm. Englewood Cliffs: Prentice-Hall.

Wolters Kluger Portugal (2006). Código das Sociedades Comerciais, Lisboa: Diário Económico, 2006, p. 58, §64. 